УдК 330.341:631.1

\section{BAPIAHTHICTЬ ФAKTOPIB РОЗВИТКУ АГРАРНОГО СЕКТОРУ НАЦІОНАЛЬНОÏ ЕКОНОМІКИ $\odot$}

\begin{tabular}{|} 
Ю.М. ЛОПАТИНСБКИЙ \\
доктор економічних наук, професор, \\
завідувач кафедри економіки \\
підприємства \\
та управління персоналом, \\
Чернівецький національний університет \\
імені Юрія Федвковича \\
(м. Чернівці), \\
ІМ. УШКАЛЕНКО, \\
Іандидат економічних наук, доцент, \\
доцент кафедри економічної \\
кібернетики, \\
Віннццький національний \\
аграрний університет \\
(м. Вінниця)
\end{tabular}

У статті подано авторське бачення актуальності та факторів розвитку аграрного сектору економіки України, окреслено відмінності та вплив варіантності та варіативності ичих факторів. Зазначена роль концепџії сталого розвитку у співставленні з тенденціями адаптації та самовиживання структурнофункиіональних елементів аграрної системи.

Розглянуто окремі тренди розвитку аграрного сектору Украӥни у варіантністному трактуванні. Установлено особливості структурного розподілу аграрного виробництва України. Означено важливість вибору та рішень сільгосптоваровиробників як фактору галузевих $i$ структурних змін, роль партнерства із стейкхолдерами. Показано складність моделювання виробничих $i$ сочіально-економічних прочесів у аграрному секторі національної економіки в умовах невизначеності та ризику, яке має трунтуватись на теорї ігор, імітачійних моделях, теоріях нечітких множин, нейронних мереж.

Спрогнозовано ймовірнісні сценарії аграрного розвитку. Запропоновано стратегії подальшого розвитку аграрного сектору наџіональної економіки.

Ключові слова: розвиток, аграрний сектор, фактори, варіантність, сценарії, національна економіка.

Літ.: 13.

\title{
VARIANCE OF THE DEVELOPMENT FACTORS OF THE NATIONAL ECONOMY AGRICULTURAL SECTOR
}

LOPATYNSKYI Yurii, Doctor of Economic Sciences, Professor, Head of the Department of Enterprise Economics and Human Resource Management, Yuriy Fedkovich Chernivtsi National University 


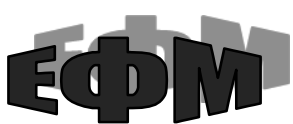

http://efm.vsau.org/

USHKALENKO Iryna,

Candidate of Economic Sciences, Associate Professor of the Department of Economic Cybernetics, Vinnytsia National Agrarian University

(Vinnytsia)

The article presents the author's vision of the actuality and factors of development of the Ukrainian economy agrarian sector; it outlines the differences and the influence of the variance and variability of these factors. The role of the concept of sustainable development in relation to the tendencies of adaptation and self-management of structural and functional elements of the agrarian system is indicated.

The separate trends of the agrarian sector development in Ukraine in the form of variant are considered. The peculiarities of structural distribution of agrarian production in Ukraine are established. The importance of agricultural producers choosing as a factor of branch and structural changes, the role of partnership with stakeholders are noted. The complexity of modeling of production and socioeconomic processes in agrarian sector of the national economy in conditions of uncertainty and risk, which should be based on the games theory, simulation models, fuzzy set theory, neural networks, are shown.

Predictable scenarios of agrarian development are suggested. The strategies of further development of the national economy agrarian sector are proposed.

Key words: development, agricultural sector, factors, variance, scenarios, national economy.

Ref.: 13.

\section{ВАРИАНТНОСТЬ ФАКТОРОВ РАЗВИТИЯ АГРАРНОГО СЕКТОРА НАЦИОНАЛЬНОЙ ЭКОНОМИКИ}

ЛОПАТИНСКИЙ Юрий Михайлович, доктор экономических наук, профессор, Черновицкий национальный университет имени Юрия Федьковича (2. Черновцы),

УШКАЛЕНКО Ирина Николаевна, кандидат экономических наук, доцент кафедры экономической кибернетики, Винницкий национальный аграрный университет (2. Винница)

В статье представлено авторское видение актуальности и факторов развития аграрного сектора экономики Украины, определень различия и влияние вариантности и вариативности этих факторов. Указана роль концепциии устойчивого развития в сопоставлении с тенденциями адаптации и выживания структурно-функииональных элементов аграрной системь.

Рассмотрень отдельные тренды развития аграрного сектора Украины в вариантной трактовке. Установлены особенности структурного распределения аграрного производства Украины. Отмечена важность выбора и решений сельхозтоваропроизводителей как фактора отраслевых и структурных изменений, 
роль партнерства со стейкхолдерами. Показана сложность моделирования производственных и социиально-экономических процессов в аграрном секторе наџиональной экономики в условиях неопределенности и риска, которое должно основываться на теории игр, имитационных моделях, теории нечётких множеств, нейронных сетей.

Спрогнозировано вероятностные сценарии аграрного развития. Предложень стратегии дальнейшего развития аграрного сектора национальной экономики.

Ключевые слова: развитие, аграрный сектор, факторы, вариантность, сценарии, национальная экономика.

\section{Лит.: 13.}

Постановка проблеми. Аграрний сектор економіки України традиційно вважається іiі локомотивом, який забезпечує зростання ВВП, вагомі експортні надходження, слугує сферою зайнятості значної частини населення країни та ін. 3 урахуванням гарантування продовольчої безпеки країни [1], мультиплікативним ефектом зв'язків із суміжними секторами національної економіки, зокрема забезпечення їх сировиною, аграрний сектор дійсно відіграє вагому роль. Хоча у розвинених країнах світу частка аграрного сектору у національному виробництві суттєво менша, ніж в Україні. При цьому вітчизняний аграрний сектор часто залишається низькоефективним, характеризується застосуванням застарілих технологій, відзначається превалюванням моновиробництва, домінуванням економічних інтересів над соціальними потребами та екологічними пріоритетами. Тож питання розвитку аграрного сектора національної економіки актуальне та важливе i, водночас, неоднозначне.

Аналіз останніх досліджень і публікацій. Розвиток аграрного сектору економіки досліджується у працях багатьох вчених, серед яких О. Бородіна, Н. Бурєннікова, І. Гончарук, Г. Калетнік, С. Коляденко, А. Мазур, М.Малік, Б. Пасхавер, Н. Пришляк, I. Прокопа, О. Прутська, О. Шпикуляк та багато ін. Спрямовані на розвиток i законодавчо-нормативні документи, наприклад, розпорядження Кабінету Міністрів України "Про схвалення Стратегії розвитку аграрного сектору економіки на період до 2020 року” від 17 жовтня 2013 р. № 806-р [2]; розпорядження Кабінету Міністрів України "Про схвалення Концепції Державної цільової програми розвитку аграрного сектору економіки на період до 2021 року” від 30 грудня 2015 р. № 1437-p [3] та ін.

Разом 3 тим, в умовах мінливого економічного та природно-кліматичного середовища функціонування аграрного сектору формується багатоваріантність його подальшого розвитку під впливом сукупності факторів, що зумовлює актуальність подальших наукових досліджень у цьому напрямі.

Формулювання цілей статті. Метою роботи є окреслення варіантності факторів і формулювання сценаріїв розвитку аграрного сектору національної економіки на засадах пропонованих стратегій.

Виклад основного матеріалу дослідження. В історично-методологічному контексті категорія "розвиток” має філософське обгрунтування. У більш прикладному розумінні щодо розвитку вагому роль відіграло становлення теорії систем, зокрема щодо соціальних систем. Саме в теорії систем розвиток розуміють як незворотну, спрямовану, закономірну зміну стану системи (об'єкта) на засадах об'єктивних закономірностей. Як відомо, характер і темпи цього процесу визначають еволюційність або революційність таких змін. Результатом розвитку стає нова якість системи. 


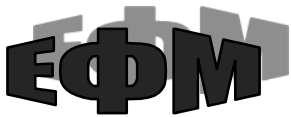

http://efm.vsau.org/

Що стосується економічного розвитку, то одним 3 фундаторів його обгрунтування вважається Й.А. Шумпетер [4], який говорив, насамперед, про появу нового, невідомого раніше, інакше кажучи, інновації. При цьому економічний розвиток потрібно відрізняти від економічного зростання (росту), хоча інколи ці поняття ототожнюються. Економічне зростання можна трактувати передусім як збільшення кількісних значень одних параметрів макро- і мікроекономічного рівня (наприклад, обсягів виробництва, прибутку та прибутковості, продуктивності праці, капіталовіддачі тощо) та зменшення значень інших параметрів (рівня інфляції, безробіття, витрат або збитків та ін.). Натомість розвиток передбачає поєднання кількісних і якісних змін, які, водночас, можуть бути тісно пов'язані. Не згадуючи тут діалектичний закон переходу кількісних змін у якісні, зауважимо, що в синергетиці (нерівноважних процесів, теорії катастроф, самоорганізації відкритих систем) оперують поняттями взаємозв'язку та взаємозалежності кількісних і якісних змін (параметрів), які у сукупності можуть призводити як до прогресу, так і до регресу, що загалом визначає протиріччя та нелінійність економічного розвитку.

3 погляду методології типологізації факторів економічного зростання трансформація економічних систем може відбуватися під дією внутрішніх i зовнішніх, прямих і непрямих факторів, які також розрізняються за рівнем регульованості. Як відомо, за прогресивністю впливу фактори можна поділити на позитивні та негативні, з погляду часу - на коротко-, середньо- та довготермінові фактори впливу. Дія різних факторів зумовлює розбіжні типи економічного зростання, зокрема екстенсивне та інтенсивне.

Адаптація системи щодо зовнішніх і внутрішніх змін безпосередньо пов’язана зі самозбереженням і визначає реальну можливість розвитку ситуації за позитивним сценарієм, наслідком якого $є$ нормалізація стану господарської системи, відновлення конкурентоспроможності та забезпечення ефективного господарювання [5, с. 57]. Самозбереження може бути визначено як властивість системи підтримувати за рахунок власної діяльності такі параметри свого стану i умов зовнішнього середовища, які б гарантували збереження цілісності системи, а також стійкий розвиток системи в подальшому [6, с. 83]. Тож важливим $є$ збалансування впливу зовнішніх (екзогенних) і внутрішніх (ендогенних) факторів щодо функціонування відкритої (соціальної) системи.

Велику роль у сучасному суспільстві стосовно економічного розвитку відіграють неекономічні фактори, значення і вплив яких тільки зростає. Серед них вагоме місце займають соціальні фактори (безпеки та забезпечення, культури й освіти, охорони здоров'я та соціального захисту та ін.).

Особливої актуальності набула усвідомлена необхідність урахування екологічних факторів, які стосуються екологічної ситуації, рівня екологічного забруднення та захисту, екологізації технологій виробництва, екологічної політики, рівня екологічної свідомості та відповідальності громадян тощо.

Сукупне врахування економічних, соціальних та екологічних факторів, як відомо, відповідає концепції сталого розвитку, пріоритети реалізації якої проголошено й в Україні. Водночас, в умовах швидкої інституціоналізації сучасного суспільства, в Україні соціальні та екологічні інституції розвинені менше, що, на нашу думку, насамперед, пов'язано із недостатнім рівнем економічного розвитку країни i, як наслідок, невисоким рівнем життя громадян, коли соціальні та екологічні питання залишаються похідними (а часом і другорядними), порівняно із 
економічними проблемами. Хоча такі закономірності, зокрема щодо екологічних питань, властиві не тільки для України. Так глобальні оцінки мега-індексу сталого розвитку (на основі даних по 31 показнику щодо основних факторів сталого розвитку по 30 країнах) засвідчують, що екологічне благополуччя виявилося удвічі менш важливішим, ніж соціально-економічне у поліпшенні добробуту людини [7].

Впливає на ситуацію й обмеженість ресурсів, яких для забезпечення високого рівня життя всіх жителів Землі та виконання програми ООН зі сталого розвитку, прийнятої у 2015 р., потрібно у шість разів більше, ніж планета може забезпечити. Тому такий рівень життя в усіх країнах одночасно неможливий [8], що вимагає пошуку альтернативних стратегій поєднання економічних, соціальних і екологічних інтересів.

Системою, де тісно переплетені економічні, соціальні та екологічні фактори, $\epsilon$ аграрний сектор і сільська місцевість, які безпосередньо взаємодіють 3 природою та відзначаються вагомим антропогенним впливом на неї. Також у сільській місцевості зазвичай нижчий рівень соціального забезпечення та захисту мешканців, менший рівень оплати праці, складніші умови праці та життя, вищий рівень безробіття тощо, що, серед іншого, “підживлює" процеси урбанізації відповідно і до світових тенденцій. Урбанізація зумовлює збідніння людського капіталу сільської місцевості, адже мігрують найактивніші ії мешканці.

За своєю специфікою аграрний сектор суттєво відрізняється від інших видів економічної діяльності. На фоні багатофункціональності аграрного сектору на його зростання впливає множина різноспрямованих факторів, що дозволяє говорити про варіантність вибору тих, які слугуватимуть рушіями аграрного розвитку. Разом із тим, дані фактори характеризуються як варіантністю, так і варіативністю, тож ці категорії потрібно розмежовувати.

Варіантність тлумачиться як наявність варіантів розвитку на засадах вибору факторів, натомість варіативність - це наявність варіацій: коливання, мінливість дії фактора(-ів). Варіативність внутрішніх і зовнішніх факторів аграрного виробництва, у тому числі природно-кліматичних, зумовлює варіативність результатів діяльності аграрного сектора. Наприклад, індекси продукції сільського господарства у господарствах усіх категорій по Україні за офіційними статистичними даними [9] засвідчують приріст порівняно з відповідним попереднім роком: 19,9\% у 2011 р., 13,3\% у 2013 p., 2,2\% у 2014 p., 6,3\% у 2016 p., 7,8\% у 2018 р. і спад 4,5\% у 2012 p., 4,8\% у 2015 р., 2,2\% у 2017 р. Тобто річні результати доволі мінливі. Разом із тим, наявність варіації другорядних факторів при незмінності основи не маскує і не гальмує визначальну тенденцію розвитку явища. Це підтверджують доволі позитивні кумулятивні результати обсягів аграрного виробництва - загальний приріст за досліджуваний період (відносно 2010 р.) становить 43,2\%. При цьому значно кращу динаміку демонструють сільськогосподарські підприємства $(+73,5 \%)$ порівняно із господарствами населення $(+14,8 \%)$, що зумовлено позитивними структурними змінами у категоріях провідних сільгосптоваровиробників. Щодо галузевої структури виробництва, то ситуація не така втішна: домінує превалювання рослинництва $(+64,8 \%)$ відносно тваринництва (лише 4,4\% приросту порівняно із 2010 р. у господарствах усіх категорій по країні в цілому). Під впливом зовнішнього середовища зменшення частки тваринництва - свідомий вибір суб'єктів аграрного сектора національної економіки.

Означені тенденції галузевих і структурних змін якраз і $є$ формою пошуку варіантів (варіантністю) забезпечення належного рівня конкурентоспроможності аграрного сектора: 1) на світовому ринку агропродовольчої продукції; 2) на 


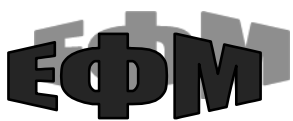

http://efm.vsau.org/

національному рівні - у формі міжсекторальної конкуренції за матеріальні та фінансові ресурси; 3) на галузевому рівні - при виборі видів сільськогосподарської діяльності (рослинництво, тваринництво, їх підвиди); 4) на мікрорівні організаційно-правових форм, розміру сільгосптоваровиробників тощо.

У контексті останньої позиції актуальною залишається різноманітність форм господарювання у аграрному секторі національної економіки. Зокрема, на фоні активного зростання агрохолдингів, дієвими залишаються інші організаційноправові форми, серед яких можна виокремити показові тенденції. Наприклад, на відміну від країн СС, де кількість фермерських господарств зменшується, в Україні вона відносно стала (з незначними коливаннями за роками), проте обсяг сільськогосподарської продукції, виробленої ними, з року в рік зростає. Не менш визначальною $\epsilon$ частка господарств населення, на які в обсязі виробництва сільськогосподарської продукції у 2018 р. (за попередніми даними) припадало 41,3\%. Показовим $\epsilon$ той факт, що коли в секторі у цілому відбувається спад, то сільськогосподарські підприємства скорочують обсяги більшою мірою (у \%), у роки зростання більший приріст також демонструють підприємства. Тобто господарства населення менше піддаються зовнішнім впливам і демонструють відносну сталість. Також у господарствах населення більша частка тваринництва, що зумовлює вищий рівень збалансованості їхньої діяльності.

Разом із тим, підсобне виробництво господарств населення здебільшого залишається формою виживання та сферою самозайнятості громадян. Тобто тут також йдеться про згадуване самозбереження. Домашні господарства загалом демонструють регресивність розвитку, проте і тут не виключений пошук гармонії, наприклад, у формі пермакультури (проектування симбіотичності агрокультур), що слугує прикладом переходу від галузевих принципів (сільськогосподарського виробництва) до просторових (аграрного сектора та сільських територій [10]), що особливо актуально стосовно регіонального розвитку та в умовах децентралізації управління, формування об’єднаних територіальних громад (ОТГ) та ін.

Те, що вибір варіантів подальшого розвитку здебільшого “в руках" самих суб'єктів аграрного сектору, підтверджує і статистичне оцінювання впливу факторів, що стримують сільськогосподарську діяльність, здійснене на основі очікувань сільськогосподарських підприємств щодо перспектив розвитку їх ділової активності (І квартал 2019 р.), серед яких відзначаються такі відповіді: “нічого не турбує” - 30\%; “погодні умови” - 21\%; “фінансові обмеження" - 17\%; “недостатній попит” - 9\% та iн. [9]. Ці результати також є аргументом стійкості аграрної системи, проте не знижують залежності сектора від зовнішніх факторів.

Загалом економіка функціонує за об’єктивними законами, проте економічна діяльність в аграрному секторі національної економіки значною мірою пов'язана із невизначеністю. Сукупність факторів невизначеності породжує ризики, які вливають на процес функціонування та розвитку економічних систем, зокрема аграрної, що зумовлює іiі особливості, серед яких найбільш вагомими є такі:

- виробництво продукції рослинництва переважно відбувається за природних умов, тож забезпечення необхідними для розвитку рослин умовами не може бути повністю контрольоване людиною;

- готова продукція тваринництва залежить від розвитку живих біологічних організмів і також виступає джерелом невизначеності; 
- підприємства сільського господарства у процесі виробництва використовують великі площі, звідси значне територіальне розрізнення господарчих підрозділів;

- усі процеси сільськогосподарського виробництва мають сезонний характер, що призводить до певної циклічності виходу готової продукції, а також витрат [11, с. 372-373].

Високий рівень варіативності параметрів ускладнює моделювання процесів у аграрному секторі національної економіки, де вагоме місце належить імовірнісним факторам. Оцінка варіативності показників при наявності адекватної моделі дозволить оцінити внесок варіативності окремих факторів виробництва у ризики аграрного виробництва на рівні країни [12, с. 161]. Це зумовлює постановку задач щодо оптимізаційних моделей $з$ метою розробки рішень, які будуть найкращими не лише в одній фіксованій ситуації, а відносно цілого набору можливих ситуацій в умовах їхньої варіантності.

Найбільш складними є оптимізаційні задачі за умов невизначеності. Серед іншого, розв'язання таких задач можливе на основі теорії ігор. Для моделювання процесів сільського господарства оптимізаційні задачі такого плану розглядаються як “гра" відносно природи [11, с. 374], проте щодо соціально-економічних відносин, пов'язаних як із внутрішніми учасниками, так i iз зовнішніми щодо аграрного сектора стейкхолдерами (зацікавленими суб'єктами та інституціями), така “гра" повинна оптимізуватися на засадах партнерства. Складність економікоматематичних моделей обмежує можливість одержання їхнього аналітичного розв'язку та зумовлює доцільність застосування імітаційних моделей, теорії нечітких множин, нейронних мереж тощо, що слугуватиме основою вибору ефективних варіантів і формування об’єктивних сценаріїв розвитку аграрного сектора національної економіки.

Варіантність розвитку аграрного сектора національної економіки визначає вагому роль державного регулювання разом із формуванням цілеспрямованого вектора аграрної політики, спрямованого на розробку стратегії розвитку. Іерархічність управління, конструктивні принципи організації та регулювання повинні забезпечити дієвість стратегії на основі програмних документів і ефективних механізмів реалізації.

Метою трансформаційних перетворень є прогностичні імперативи належний рівень та якість життя суб'єктів аграрного сектору та сільської місцевості (громадян). Інструментом реалізації має слугувати, насамперед, стратегія розвитку. За результатами наших досліджень можемо окреслити такі стратегії розвитку аграрного сектора національної економіки:

1) стратегія розвитку інституції власності в аграрному секторі: інституційного врегулювання правового режиму землекористування, купівлі-продажу прав оренди, протидії рейдерству тощо;

2) стратегія розвитку форм аграрного господарювання: створення умов забезпечення ефективності функціонування сільгосптоваровиробників різних організаційно-правових форм і розмірів, стримування агрохолдингізації аграрного сектора національної економіки;

3) стратегія розвитку аграрного підприємництва: пошук i розвиток ефективних видів економічної діяльності в агарному секторі, диверсифікація ризиків. Серед варіантів - “зелене” підприємництво [13], виробництво органічної продукції, активізація агротуризму та ін. Для малих виробників, фермерських господарств, 


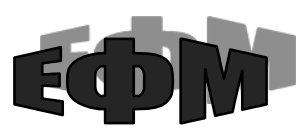

http://efm.vsau.org/

господарств населення - виробництво як нетоварних до недавнього часу (горіхи, мед тощо), так і нішових культур: ягідних (полуниця, лохина, кизил, жимолость), олійних (гірчиця, кунжут, льон олійний, сафлор, рижій), овочевих (спаржа), пряних (меліса), ефірних (м'ята, лаванда, гісоп), лікувальних та багатьох інших;

4) стратегія розвитку державного регулювання й адаптивного мікроменеджменту: збалансування регулювання на різних інституційних рівнях, зокрема, посилення ефективності державного регулювання і збалансованості державної підтримки, зростання ролі самоврядування на сільській території, спрямованих на розвиток неаграрних видів економічної діяльності у сільській місцевості, у тому числі і сполучених (наприклад, переробка аграрної продукції та ін.);

5) інституціоналізація аграрного сектору: трансформація попередніх (звичок, традицій) і впровадження нових, насамперед, неформальних інституцій (правил ведення та етики бізнесу, ділових узвичаєнь тощо), об'єднань (спілок, асоціацій виробників, продавців та ін.). Формування інституцій громадського регулювання та громадянського суспільства.

Заключним елементом $є$ розробка сценаріїв розвитку аграрного сектору національної економіки як варіантів його довгострокового розвитку. Авторський прогноз подальшого розвитку аграрного сектору грунтується на методі логіки можливого розвитку й охоплює три ймовірнісні сценарії: песимістичний, реалістичний, оптимістичний.

Песимістичний сценарій - аграрний сектор залишиться на сьогоднішньому рівні без суттєвих змін або зміни будуть непринципові. Вихідною передумовою цього $\epsilon$ адаптація системи щодо зовнішніх $\mathrm{i}$ внутрішніх факторів на принципах самозбереження. Сценарій неприйнятний.

Реалістичний сценарій - диверсифікація видів економічної діяльності малих і середніх виробників, посилення концентрації та монополізації на рівні агрохолдингів. Цей сценарій прийнятний 3 погляду економічних, але не соціальноекологічних інтересів.

Оптимістичний сценарій - зміна принципів державного регулювання та місцевого самоврядування, підвищення ефективності аграрного виробництва, розвиток аграрного сектору на основі багатоукладності, балансу інтересів стейкхолдерів, залучення інвестицій i впровадження інновацій в умовах сприятливого внутрішнього середовища аграрного сектору. Цей сценарій визначається меншими екологічними та соціальними екстерналіями, вищим рівнем збалансованості та сталості розвитку. Сценарій бажаний як 3 позицій аграрного сектору, так і суспільства в цілому.

Висновки. Ефективний розвиток аграрного сектору є багатоваріантним та актуальним для України і відбувається під впливом сукупності різноманітних факторів. Оптимізації факторної системи сприятиме удосконалення аграрної політики та дієвість стратегії розвитку, доповнені адаптивними рішеннями децентралізованої системи регулювання, позитивним впливом неформальних інституцій, диверсифікацією аграрного виробництва та ризиків, партнерством стейкхолдерів. Варіантність розвитку подій характеризується можливими сценаріями (песимістичним, реалістичним, оптимістичним), проте подолання “хаосу” в нелінійній динамічній системі, як відомо, вимагає докладання зусиль. 


\section{Eक \\ http://efm.vsau.org/}

Перспективами подальших розвідок у даному напрямі можна вважати економіко-математичне моделювання варіантності розвитку аграрного сектора національної економіки.

\section{Список використаних джерел}

1. Калетнік Г. М., Дармограй О. В. Методичні підходи до оцінки та аналіз індикаторів продовольчої безпеки України. Економіка. Фінанси. Менеджмент: актуальні питання науки $i$ практики. 2016. № 6. С. 7-20. URL: http://efm.vsau.org/files/pdfa/2999.pdf (дата звернення: 02.04.2019).

2. Про схвалення Стратегії розвитку аграрного сектору економіки на період до 2020 року : Розпорядження Кабінету Міністрів України від 17 жовтня 2013 р. № 806p. URL: https://zakon.rada.gov.ua/laws/show/806-2013-р (дата звернення: 02.04.2019).

3. Про схвалення Концепції Державної цільової програми розвитку аграрного сектору економіки на період до 2021 року : Розпорядження Кабінету Міністрів України від 30 грудня 2015 р. № 1437-p. URL: https://zakon.rada.gov.ua /laws/show/1437-2015-р (дата звернення: 02.04.2019).

4. Шумпетер Й. А. Теорія економічного розвитку. Дослідження прибутків, капіталу, кредиту, відсотку та економічного циклу; пер. 3 англ. Київ : КиєвоМогилянська академія, 2011. 242 с.

5. Прушківський В. Г., Куценко В. І. Закони розвитку та самозбереження у сільському господарстві. Економічний вісник. 2014. № 1. С. 56-63. URL: http://ev.nmu.org.ua/docs/2014/1/EV20141_056-063.pdf (дата звернення: 02.04.2019).

6. Снопенко Г. Г. Синергетична функція самозбереження - складова основи самоорганізації економічних систем в забезпеченні економічної безпеки підприємств. Часопис економічних реформ. 2013. № 3. С. 82-88.

7. Richard Ross Shaker. A mega-index for the Americas and its underlying sustainable development correlations. Ecological Indicators. 2018. Vol. 89. P. 466-479. URL: https://www.sciencedirect.com/science/article/pii/S1470160X18300530. https:// doi.org/10.1016/j.ecolind.2018.01.050 (Last accessed: 02.04.2019).

8. Daniel W. O’Neill, Andrew L. Fanning, William F. Lamb and Julia K. Steinberger. A good life for all within planetary boundaries. Nature sustainability. 2018. Vol. 1. P. 88-95. URL: www.nature.com/articles/s41893-018-0021-4.epdf (Last accessed: 02.04.2019).

9. Державна служба статистики України: веб-сайт. URL: http://www.ukrstat.gov.ua (дата звернення: 02.04.2019).

10. Аграрний і сільський розвиток для зростання та оновлення української економіки : наукова доповідь / за ред. чл.-кор. НАН України Бородіної О.М., д-ра екон. наук Шубравської О.В. Київ : ДУ «Ін-т екон. та прогнозув. НАН України», 2018. 152 c. URL: http://ief.org.ua/docs/sr/298.pdf (дата звернення: 02.04.2019).

11. Шиш I.M. Особливості моделювання сільськогосподарського виробництва 3 врахуванням ризику. Науковий вісник ЛНУВМБТ імені С.3. Гжицького. 2012. Том 14. № 1(51), Част. 2. С. 369-374.

12. Скрипник А. В., Яра Т. Ю. Вплив варіативності окремих факторів на аграрне виробництво. Проблеми економіки. 2014. № 4. С. 161-169. URL: http://www.problecon.com/export_pdf/problems-of-economy-2014-4_0-pages161_169.pdf (дата звернення: 02.04.2019). 


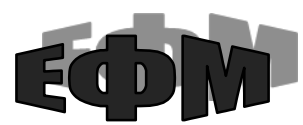

http://efm.vsau.org/

13. Калетнік Г. М., Козак К. В. Зелений бізнес - перспектива підприємництва. Економіка. фінанси. менеджмент: актуальні питання науки і практики. 2016. № 12 . C. 7-15. URL: http://efm.vsau.org/files/pdfa/3406.pdf (дата звернення: 02.04.2019).

\section{References}

1. Kaletnik, G. M., \& Darmohrai, O. V. (2012). Metodychni pidkhody do otsinky ta analiz indykatoriv prodovolchoi bezpeky Ukrainy [The methodological approaches to the evaluation and analysis of the indicators of food security in Ukraine]. Ekonomika. Finansy. Menedzhment: aktualni pytannia nauky i praktyky - Economy. Finances. Management: topical issues of science and practice, 6, 7-20. Retrieved from http://efm.vsau.org/files/pdfa/2999.pdf [in Ukrainian].

2. Rozporiadzhennia Kabinetu Ministriv Ukrainy «Pro skhvalennia Stratehii rozvytku ahrarnoho sektoru ekonomiky na period do 2020 roku» [Order of the Cabinet of Ministers of Ukraine «On approval of the Strategy for the development of the agrarian sector of the economy for the period up to 2020»]. (2013). https://zakon.rada.gov.ua. Retrieved from https://zakon.rada.gov.ua/laws/show/806-2013-p [in Ukrainian].

3. Rozporiadzhennia Kabinetu Ministriv Ukrainy «Pro skhvalennia Kontseptsii Derzhavnoi tsilovoi prohramy rozvytku ahrarnoho sektoru ekonomiky na period do 2021 roku» [Order of the Cabinet of Ministers of Ukraine «On Approval of the Concept of the state target program for the development of the agricultural sector for the period until 2021»]. (2015). https://zakon.rada.gov.ua. Retrieved from https://zakon.rada.gov.ua /laws/show/1437-2015-p [in Ukrainian].

4. Schumpeter, J.A. (2011). Teoriia ekonomichnoho rozvytku. Doslidzhennia prybutkiv, kapitalu, kredytu, vidsotku ta ekonomichnoho tsyklu [The theory of economic development: an inquiry into profits, capital, credit, interest, and the business cycle]. Kyiv: Kyievo-Mohylianska akademiia, 242 [in Ukrainian].

5. Prushkivskyi, V.H., \& Kutsenko, V.I. (2014). Zakony rozvytku ta samozberezhennia u silskomu hospodarstvi [Laws of development and self-preservation in agriculture]. Ekonomichnyi visnyk - Economic Herald, 1, 56-63. Retrieved from http://ev.nmu.org.ua/docs/2014/1/EV20141_056-063.pdf [in Ukrainian].

6. Snopenko, H.H. (2013). Synerhetychna funktsiia samozberezhennia - skladova osnovy samoorhanizatsii ekonomichnykh system v zabezpechenni ekonomichnoi bezpeky pidpryiemstv [The synergetic self-preservation function as an integral part of the selforganization of economic systems in providing economic security to enterprises]. Chasopys ekonomichnykh reform - Journal of Economic Reforms, 3, 82-88 [in Ukrainian].

7. Richard Ross Shaker. (2018). A mega-index for the Americas and its underlying sustainable development correlations. Ecological Indicators, 89, 466-479. Retrieved from https://www.sciencedirect.com/science/article/pii/S1470160X18300530, https://doi.org/10.1016/j.ecolind.2018.01.050.

8. Daniel W. O’Neill, Andrew L. Fanning, William F. Lamb \& Julia K. Steinberger. (2018). A good life for all within planetary boundaries. Nature sustainability, 1, 88-95. Retrieved from www.nature.com/articles/s41893-018-0021-4.epdf.

9. Derzhavna sluzhba statystyky Ukrainy : veb-sait [State Statistics Service of Ukraine: website]. Retrieved from http://www.ukrstat.gov.ua [in Ukrainian].

10. Borodina, O.M., \& Shubravska. O.V. (Eds.). (2018). Ahrarnyi i silskyi rozvytok dlia zrostannia ta onovlennia ukrainskoi ekonomiky: naukova dopovid [Agrarian and rural development for growth and renewal of the Ukrainian economy: scientific report]. Kyiv: DU «In-t ekon. ta prohnozuv. NAN Ukrainy». Retrieved from http://ief.org.ua /docs/sr/298.pdf [in Ukrainian]. 


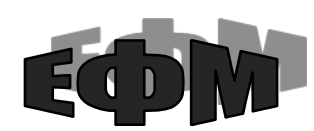

http://efm.vsau.org/

11. Shysh, I.M. (2012). Osoblyvosti modeliuvannia silskohospodarskoho vyrobnytstva $\mathrm{z}$ vrakhuvanniam ryzyku [Features of modeling agricultural production based on risk]. Naukovyi visnyk Lvivskoho natsionalnyi universytetu veterynarnoi medytsyny ta biotekhnolohii imeni S.Z. Hzhytskoho - Scientific Herald of Stepan Gzhytskyi National University of Veterinary Medicine and Biotechnologies. Lviv, 14, 1(51), part 2, 369-374 [in Ukrainian].

12. Skrypnyk, A.V., \& Yara, T.Yu. (2014). Vplyv variatyvnosti okremykh faktoriv na ahrarne vyrobnytstvo [Influence of variability of individual factors on agrarian production]. Problemy ekonomiky - Problems of the economy, 4, 161-169 Retrieved from http://www. problecon.com /export_pdf /problems-of-economy-2014-4_0-pages161_169.pdf [in Ukrainian].

13. Kaletnik, H.M., \& Kozak, K.V. (2016). Zelenyi biznes - perspektyva pidpryiemnytstva [Green business - the prospect of entrepreneurship]. Ekonomika. Finansy. Menedzhment: aktualni pytannia nauky $i$ praktyky - Economy. Finances. Management: topical issues of science and practice, 12, 7-15. Retrieved from http://efm.vsau.org/files/pdfa/3406.pdf [in Ukrainian].

\section{Інформація про авторів}

ЛОПАТИНСБКИЙ Юрій Михайлович - доктор економічних наук, професор, завідувач кафедри економіки підприємства та управління персоналом, Чернівецький національний університет імені Юрія Федьковича (58012, м. Чернівці, вул. Коцюбинського, 2, e-mail: y.lopatynskyi @chnu.edu.ua).

УШКАЛЕНКО Ірина Миколаївна - кандидат економічних наук, доцент, доцент кафедри економічної кібернетики, Вінницький національний аграрний університет (21008, м. Вінниця, вул. Сонячна, 3, e-mail: irinavnau @ gmail.com).

LOPATYNSKYI Yurii - Doctor of Economic Sciences, Professor, Head of the Department of Enterprise Economics and Human Resource Management, Yuriy Fedkovich Chernivtsi National University (58012, Chernivtsi, 2 Kotsyubynskyi Str., e-mail: y.lopatynskyi@chnu.edu.ua).

USHKALENKO Iryna - Candidate of Economic Sciences, Associate Professor, Associate Professor of the Department of Economic Cybernetics, Vinnytsia National Agrarian University (21008, Vinnytsia, 3 Soniachna Str., e-mail: irinavnau@gmail.com).

ЛОПАТИНСКИЙ Юрий Михайлович - доктор экономических наук, профессор, Черновицкий национальный университет имени Юрия Федьковича (58012, г. Черновцы, ул. Коцюбинского, 2, e-mail: y.lopatynskyi@chnu.edu.ua).

УШКАЛЕНКО Ирина Николаевна - кандидат экономических наук, доцент кафедры экономической кибернетики, Винницкий национальный аграрный университет (21008, г. Винница, ул. Солнечная, 3, e-mail: irinavnau @gmail.com).

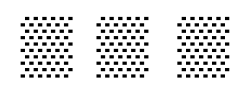

